\title{
A cirkuláris ribonukleinsav és tumorbiológiai jelentősége
}

\author{
Turai Péter István dr. - Igaz Péter dr. \\ Semmelweis Egyetem, Általános Orvostudományi Kar, II. Belgyógyászati Klinika, Budapest
}

\begin{abstract}
Az utóbbi évek molekuláris biológiai kutatásainak egyik legjelentősebb fejezete a nem kódoló ribonukleinsavak (RNS-ek) kutatása. A nem kódoló RNS-ek csoportján belül külön csoportot képeznek a cirkuláris RNS-ek, amelyek jelentőségét mostanában kezdjük megismerni. E rendkívül stabil molekulák többféle mechanizmuson keresztül - például a szintén nem kódoló RNS-ek családjába tartozó mikro-RNS-ek megkötése vagy a transzláció befolyásolása révén - vesznek részt a génexpresszió szabályozásában. A cirkuláris RNS-ek kifejeződésének megváltozását több daganatban leírták, ami stabilitásuk révén biomarkerként történő alkalmazásukat vetíti elöre, illetve molekuláris célpontként is szóba jöhetnek. Összefoglaló cikkünkben a cirkuláris RNS-ek általános jellemzőit és tumorbiológiai jelentőségét mutatjuk be.
\end{abstract}

Orv Hetil. 2020; 161(11): 403-412.

Kulcsszavak: nem kódoló RNS, cirkuláris RNS, mikro-RNS, daganat, biomarker

\section{Circular ribonucleic acid and its tumor-biological relevance}

One of the most remarkable chapters in recent years' research of molecular biology is the quest for non-coding ribonucleic acids (RNAs). Circular RNAs form a distinct group within non-coding RNAs and their significance is being discovered only now. These uncommonly stable molecules take part in the regulation of gene expression by various mechanisms, e.g., by decoying microRNAs or by acting upon the translational machinery. The altered expression of circular RNAs was described in different types of cancers, and considering their stability, circular RNAs could be exploited as future biomarkers and even as molecular targets. In this synopsis, the authors present the biological characteristics and the tumor-biological relevance of circular RNAs.

Keywords: non-coding RNA, circular RNA, microRNA, tumor, biomarker

Turai PI, Igaz P. [Circular ribonucleic acid and its tumor-biological relevance]. Orv Hetil. 2020; 161(11): $403-412$.

(Beérkezett: 2019. október 29; elfogadva: 2019. november 26.)

\section{Rövidítések}

$\mathrm{CDRl}$ as $=($ cerebellar degeneration-related protein $\mathrm{l}$ antisense transcript) a cerebellaris degeneratióhoz kapcsolt fehérje-1 antiszensz transzkriptuma; cfDNS $=$ (cell-free DNA) szabadon keringő DNS; circRNS = cirkuláris RNS; ciRNS = csak intronokat tartalmazó cirkuláris RNS; DNS = dezoxiribonukleinsav; EIciRNS = exon-intron szekvenciákat tartalmazó cirkuláris RNS; EMT = (epithelial-to-mesenchymal transition $)$ epithelialis-mesenchymalis átalakulás; eRNS = enhancer RNS; exRNS = extracellularis RNS; f-circRNS = fúziós cirkuláris RNS; GWAS $=($ genom-wide association study $)$ genomi szintű asszociációs vizsgálat; $\mathrm{HDL}=$ (high-density lipoprotein) nagy sürüségú lipoprotein; lncRNS = (long non-coding RNA) hosszú nem kódoló RNS; IRES = (internal ribosome entry site) belső ribosomabelépési hely; miRNS, $\mathrm{miR}=$ mikro-RNS; $\mathrm{mRNS}=($ mes- senger RNS) hírvivő RNS; ncRNS = (non-coding RNA) nem kódoló $\mathrm{RNS}$; ORF $=$ (open reading frame) nyitott leolvasási keret; PAR = promóterasszociált RNS; piRNS = Piwi-interact ing RNS; RBP = (RNA-binding protein) RNS-kötő fehérje; RNAPII = RNS-polimeráz-II; RNA-seq $=($ RNA sequencing $)$ RNS-szekvenálás; RNáz R = ribonukleáz R; RNS = ribonukleinsav; $r$ RNS $=$ ribosomalis RNS; RT- $\mathrm{PPCR}=$ (reverse transcription-quantitative polymerase chain reaction) reverz transzkripcióhoz kapcsolt kvantitatív polimeráz-láncreakció; siRNS = (small interfering RNA) kis interferáló RNS; snRNS = (small nuclear RNA) kis magi RNS; snoRNS = (small nucleolar RNA) kis nukleoláris RNS; SNP = (single-nucleotide polymorphism) egy nukleotidot érintő polimorfizmus; $\mathrm{TF}=$ (transcription factor) átíródási tényező; tRNS = transzfer-RNS; UTR = (untranslated region) le nem fordítódó régió/szakasz 
Az utóbbi évtized felfedezéseinek köszönhetően a molekuláris biológia nemcsak hatalmas fejlődésen ment keresztül, hanem egy paradigmaváltás kapujába is került. Összefoglaló cikkünkben a génexpresszió szabályozásának egy nemrégiben „újra felfedezett” apparátusát kívánjuk bemutatni, és annak daganatbiológiai jelentőségét. Az utóbbi évtizedek eredményei azt mutatják, hogy az RNS nemcsak mint a DNS és a fehérjék közötti hírvivő játszik fontos szerepet, hanem magában a génexpreszszióban és a genom szabályozásában is alapvető funkciót tölt be.

A már négy évtizede felfedezett cirkuláris RNS-nek (circRNS) eleinte nem tulajdonítottak érdemi biológiai funkciót, a normál splicing mechanizmus hibáinak vélték. Az ez irányú kutatások háttérbe szorulására magyarázatot adhat aktív keresésük hiánya, hiszen izolálásuk és bioinformatikai analízisük módszertanilag eltér a lineáris RNS-ek kimutatásától. Kutatásuk jelentőségéhez manapság már nem fér kétség, habár pontos funkcióik jelenleg sem teljesen tisztázottak. A circRNS-eket övező, egyre nagyobb figyelem a tumorgenezisben betöltött szerepüknek, a szövetekben és testfolyadékokban egyaránt igen stabil szerkezetüknek és lineáris partnereikhez képest is eltérő szövetspecifikus kifejeződésüknek köszönhető. Cikkünkben a cirkuláris RNS-ről alkotott jelenlegi tudásunkat kívánjuk kontextusba helyezni, kezdve annak biogenezisével, majd a tumorprogresszióban, diagnosztikai és prognosztikai biomarkerként betöltött szerepére is kitérve a személyre szabott medicinában.

\section{A nem kódoló RNS-ek biológiai szerepe}

A nem kódoló RNS-ek (ncRNS) felfedezéséhez az egész genomra kiterjedő tanulmányok vezettek el, amelyek többek között - kimutatták az emlősgenom jelentős, RNS-re való átíródását. A nagy áteresztőképességú transzkriptomikai vizsgálatok megdöbbentő módon azt mutatták, hogy az eukaryota-DNS 90\%-a átíródik RNSre, amelyből mindössze 1-2\% kódol fehérjét, míg a túlnyomó többség ncRNS. A korábban passzívnak vélt, nem kódoló genom, a ncRNS-ek és emellett egy sor, hozzájuk kapcsolható mechanizmus azonosításával a génexpresszió egy teljesen új szabályozási mechanizmusát fedezték fel [1].

Az ncRNS-eket tovább lehet bontani infrastrukturális RNS-ekre és szabályozó RNS-ekre. A folyamatosan kifejeződő infrastrukturális RNS-ek közé tartozik a ribosomalis RNS (rRNS), a transzfer-RNS (tRNS), a small nuclear RNS (snRNS) és a small nucleolar RNS (snoRNS). A szabályozó RNS-ek pedig tovább osztályozhatók, mint mikro-RNS (miRNS, miR), cirkuláris RNS (circRNS), Piwi-interacting RNS (piRNS), small interfering RNS (siRNS), hosszú nem kódoló RNS (lncRNS, 200 nukleotidnál hosszabb), promóterasszociált RNS (PAR) és enhancer RNS (eRNS) [2-4].

\section{Mikro-RNS-ek: az RNS-interferencia szabályozói}

A miR-ek rövid, 19-25 nukleotidból álló, evolúciósan konzervált, a legtöbbször külön miRNS-gének által kódolt, érett formáikban egyszálú molekulák, amelyek a humán gének kb. 30-60\%-át szabályozzák poszttranszkripcionális szinten, az epigenetikai - a DNS-szekvencia megváltoztatásával nem járó - szabályozás keretében [5]. A miRNS-ek részben a génexpresszió elsődleges regulátorának tartott transzkripciós faktorokhoz (TF) hasonlóan fejtik ki hatásukat. Míg a TF-ok a gén promóterrégiójának specifikus szekvenciájához kötődve fejtik ki aktiváló vagy csendesítő hatásukat, addig a miRNS-ek a citoplazmában az mRNS-ekhez kötődve járulnak hozzá azok transzlációjának gátlásához (degradációjához vagy csendesítéséhez) a $3^{\prime}$ le nem fordítódó régióhoz kötődve (UTR: untranslated region) [6]. Az utóbbi évek megfigyelései arra is utalnak, hogy a miRNS-ek a sejtmagban is funkcióval bírnak, ahol a géntranszkripció- és hisztonfehérjék modifikációjában írták le szerepüket $[7,8]$. A miRNS-ek biológiai funkcióinak bizonyítékai ma már bőségesen rendelkezésre állnak. Pleiotrop hatásaikra példa a sejtciklus, -differenciálódás, sejtproliferáció, hormonszekréció és apoptózis szabályozása, továbbá szerepük van a vérképzésben és az egyedfejlődésben, másrészt megváltozott expressziójuk révén hozzájárulnak daganatok, autoimmun és érrendszeri betegségek kialakulásához [9]. További figyelemre méltó tulajdonságuk a szöveti specificitásuk. A miRNSek szövetspecifikus kifejeződése a különböző szövetekben eltéró miRNS-profilt hoz létre az emberi szervezetben. Jelenleg körülbelül 2500 miRNS ismert emberben [10]. Patogenetikai jelentóségüket alátámasztja az a tény, hogy míg egy miRNS egy adott szövetben/sejtben betölthet aktiváló/csendesító funkciót, lehetséges, hogy egy másik szövetben/sejtben épp az előbbivel ellentétes vagy eltérő mértékú hatást hoz létre [6]. Ennek megfelelően ugyanaz a miRNS az egyik szövetben tumorszuppresszor, míg a másikban onkogén hatású is lehet. Példa az előbbi jelenségre a miR-24, amelynek colorectalis daganatokban csökkent kifejeződését, hepatocellularis carcinomában pedig túlzott expresszióját figyelték meg [11, 12]. A miRNS-ek a kódoló RNS-eknél mutatott hosszabb felezési idejük és stabilitásuk miatt jól vizsgálhatók formalinfixált paraffinba ágyazott szövetmintákon, továbbá megtalálhatók testfolyadékokban, így a vérben is $[13,14]$. Az utóbbiak az ún. keringő miRNS-ek, amelyek passzívan necrosis, gyulladás révén vagy aktívan membránhólyagocskákban (exosomák, microvesiculák) és makromolekuláris komplexek (Ago, HDL) segítségével szabadulhatnak fel [15-17]. Különösen az exosomalis miRNS-ek vetik fel annak lehetőségét, hogy a keringő miRNS-ek az epigenetikai információ hormonszerú továbbítói lehetnek. Mindezen tulajdonságokat figyelembe véve a miRNS-ek jelenleg 
az egyik leginkább kutatott terület a daganatos és nem daganatos betegségek terápiájában és minimálisan invazív diagnosztikájában egyaránt - kiemelve a szövettanilag is nehezen differenciálható mellékvese- és pajzsmirigyrákokat [18].

\section{A cirkuláris RNS-ek}

Az utóbbi idők felfedezései tárták fel előttünk, hogy gének ezrei körkörösen zárt szerkezetű RNS-eket expreszszálnak (az aktív gének expressziójának végterméke 5-20\%-ban circRNS) [19]. Sokan közülük tartalmaznak ugyan exonokat, de fehérjék csak ritkán képződnek róluk. A circRNS-ek a nem kódoló genom egy új fajtáját alkotják, s a génexpressziót fóként poszttranszkripcionális szinten befolyásolják. E hatásokat a DNS bázissorendjének megváltoztatása nélkül, epigenetikai úton érik el. A circRNS-ek nevüket a kovalens kötéssel bezárt struktúrájuknak köszönhetik. A pre-mRNS-ból (még nem teljesen érett, intronokat is tartalmazó forma) képződnek egy „backsplicing”-nak nevezett folyamat során, amikor is kialakul a $3^{\prime}$-vég és az $5^{\prime}$-vég közötti kovalens kötés [20]. A circRNS-ek kifejeződésének mértéke eltér a megfelelő lineáris RNS-ek kifejeződésétől. Ez azzal magyarázható, hogy a circRNS-ek képződése nem a hordozó gének kifejeződésével áll összefüggésben, hanem alapvetôen az intron szerkezete (repetitív, reverz komplementer szekvenciák) határozza meg a backsplicing gyakoriságát [21]. A splicing mechanizmustól függően összességében három osztályát különböztetjük meg a circRNS-eknek. A nukleáris lokalizációjú 2'-5' circRNS-t, amely csak intronokat tartalmaz (ciRNS); a szintén nukleáris lokalizációjú, 3'-5' exon-intron szekvenciákat tartalmazó EIciRNS-t és a leggyakoribb citoplazmatikus lokalizációjú 3'-5' exonális circRNS-t. A circRNS-ekre szövetspecifikus kifejeződés jellemző, mi több, a kvantifikációs adatokból kimutatható, hogy nem csupán donor és akceptor véletlenszerü fúziójáról, hanem különböző szabályozómechanizmusok összjátékáról van szó [22]. A szövetspecifikus kifejeződés oka jelenleg még nem teljesen tisztázott.

Funkciójukat tekintve a circRNS-ek részt vesznek a neuralis múködésben, a veleszületett immunitásban, a sejtproliferációban csakúgy, mint a különböző szolid (colorectalis rák, hepatocellularis rák, tüdőrák, glioma, osteosarcoma stb.) és hematológiai tumorok kialakulásában [23]. A génexpressziót a miRNS-ek "szivacsként” való megkötése, a fehérjeszekvesztráció, az RNS-polimeráz-II (RNAPII) modifikálása és a pre-mRNS-képződés gátlása révén befolyásolják. Továbbá egyes circRNS-ek transzlálódáson mehetnek keresztül, mások pedig pszeudogének (olyan nukleotidszekvenciák, amelyek csak látszólag kódolnak egy génterméket, de az vagy funkcióképtelen, vagy ki sem fejeződik) forrásai lehetnek, ez utóbbi például génkettőződés révén az RNS körkörös szerkezete miatt [24].

\section{A cirkuláris RNS-ek bioszintézise}

A biogenezis megértésének és kutatásának klinikai relevanciáját a megfelelő biomarkerek kiválasztása és a tumorgenezissel való kapcsolatának feltárása támasztja alá. Az oly sok tumorban már megfigyelt aberráns circRNSexpresszió ugyanis részben magyarázható a biogenezisben bekövetkező genetikai és epigenetikai módosulásokkal [25].

Az RNS-ek cirkularizálódása a leggyakrabban a spliceosomán keresztül (RNS és fehérjék szupramolekuláris komplexe) következik be a pre-mRNS-ből az RNAPII és a hordozó gének segítségével. A circRNS szintézise különböző endogén és exogén hatásokra néhány napos, hetes reakcióidővel képes fokozott vagy csökkent kifejeződést mutatni. A spliceosoma általi cirkularizálódás három úton jöhet létre. Az első: a kolineáris splicingot követően a kivágott introni RNS- „lasszó” cirkuláris RNS-sé rendeződik (2'-5' forma). A második a kotranszkripcionális backsplicing segítségével az exon cirkularizációja ( $3^{\prime}-5^{\prime}$ exonális forma). A harmadik a poszttranszkripcionális backsplicing exont és intront is tartalmazó „lasszó” cirkularizációja ( $3^{\prime}-5^{\prime}$ exon-intron forma). A folyamatból is adódóan a circRNS-eknek nincs poly(A)-farkuk, 5 '-sapkájuk és szabad végződésük, s ezen tulajdonságok és az RNáz R-rel (3'-5' exonukleáz) szembeni rezisztencia miatt a felezési idejük 2-10-szer hosszabb (19-48 óra) lineáris mRNS-,társaikénál” (azonos génről átíródó; rokon mRNS), illetve kimutatásuk is részben RNáz R-előkezelés után lehetséges [26, 27]. A transzkripciós végtermékeknek azonban csak egy kis százalékát teszik ki a circRNS-ek. Lineáris társaikhoz képest csupán 5-10\%-ot tesznek ki, ugyanakkor vannak gének, amelyek az mRNSeknél több circRNS-t expresszálnak. Ehhez hasonlóan a vérlemezkékben a jóval tartósabb circRNS-ek relatív többségéhez vezet, hogy azok érésük során sejtmagjukat, ezzel együtt további transzkripciós potenciáljukat elvesztik, ami a rövidebb életû mRNS-ek relatív hiányához vezet. A vérlemezkéken kívül még a neuronokban is egészen magas circRNS-szintet figyeltek meg, aminek oka jelenleg még nem teljesen tisztázott $[28,29]$. Emellett a circRNS-ek 90\%-a sejtenként csak 1-10 molekulapéldányból áll (az mRNS-ek mediánja 17 molekula/ sejt), mindazonáltal sejtenként átlagosan 25000 izoforma mennyiséget ér el, ami a circRNS-ek sokszínúségének tudható be. Evolúciós konzerváltságát illetően igen jelentősnek vélt 15\%-os átfedés mutatkozott az ember és az egér circRNS-készlete között. Méretüket tekintve átlagosan 547 nukleotidból állnak, s ez megfelel a ténynek, miszerint átlagosan 1-5 exont tartalmaznak, amelyek körülbelül 20-200 nukleotid hosszúak [22].

\section{A cirkuláris RNS-ek potenciális biológiai jelentősége}

A kísérleti bizonyítékok alapján a circRNS-ek kétféleképpen fejtik ki biológiai hatásukat. Először is maga a 


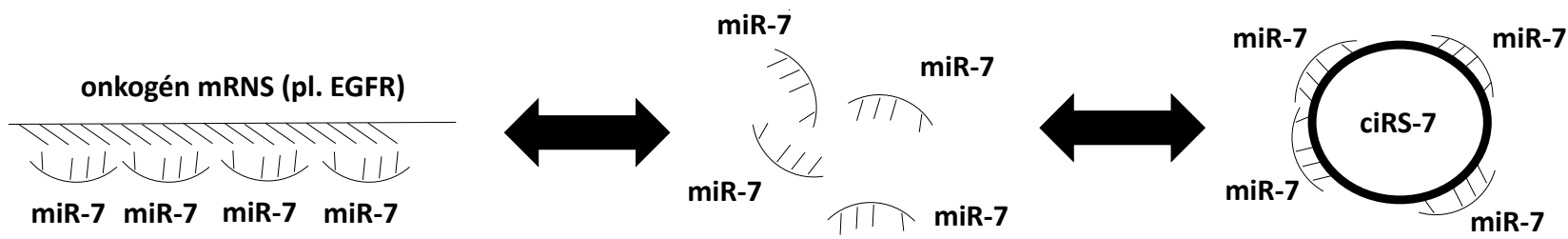

A miR-7 onkogének kifejeződését gátolja

A ciRS-7 gátolja a miR-7-et

1. ábra

A cirkuláris RNS-ek miRNS-,„szivacs”-funkciója. A ciRS-7 jelenlétében a miR-7 nem képes gátolni az onkogének kifejeződését; nyíl: a miR-7 egyensúlyi állapotának eltolódása aktív (balra), illetve passzív (jobbra) irányba

ciRS-7 = cirkuláris RNS; EGFR = epidermális növekedési faktor receptor; miR-7 = mikro-RNS; RNS = ribonukleinsav

circRNS kialakulásának folyamata is biológiai hatással bír, másrészt a kialakult termékek transzregulációs képességgel bírnak. Mind ez idáig csak néhány circRNS-t tanulmányoztak részletesebben, s ezekról lesz szó a továbbiakban. A circRNS-ek a génexpresszióra kifejtett hatásaikat hat különböző módon érhetik el: l) a fentebb már részletezett miRNS-ek szekvesztrálása révén „szivacsként” képesek azokat inaktiválni; 2) a circRNS-ek stimulálni tudják a gének RNAPII általi iniciációját, elongációját; 3 ) hozzájárulnak a rokon lineáris mRNS-ek csökkent kifejeződéséhez a lineáris splicing csökkentése révén; 4) fehérjékhez kötődve gátolják a ribosomabioszintézissel és -transzlációval járó folyamatokat; 5) néhány circRNS képes fehérjét kódolni, amennyiben tartalmaz ún. nyitott leolvasási keretet (ORF) és ribosomakapcsolódási helyet; 6) végül a circRNS-ek képesek enzimatikus folyamatokat katalizálni az enzimek és szubsztrátjaik között $[22,30]$.

1. A közelmúltban kimutatták, hogy a citoplazmatikus ncRNS-ek képesek a miRNS-eket szivacsként befogni, ezáltal a kódoló RNS-eket felszabadítva a lebomlástól, utat engednek transzlációjuknak [22]. A legelső jelentések a CDRlas (cerebellar degeneration-related protein
1 antisense transcript) gén transzkriptumát vizsgálták (más néven ciRS-7), amely bőségesen tartalmaz miRNSkötő helyeket a miR-7 számára (1. ábra). Ezen vizsgálatok szerint a miRNS-circRNS duplexen belül létrejövő mismatchek (a „seed” [magi] régió tökéletes egyezésén kívül) elejét veszik a circRNS RISC-dependens lebontásának, továbbá a kettejük kolokalizációját is bizonyították RNS-FISH-eljárással [31]. A „miRNS-szivacsok” nem túl gyakoriak a circRNS-ek funkciói között, már ami a genomikus mércét illeti, kitüntetett esetekben azonban valódi funkcionalitással bírnak.

2. Több száz circRNS-t hoztak már összefüggésbe a transzkripcióban részt vevő RNAPII-komplex szabályozásával. Ezek között találunk exon-intron szekvenciát kódoló (EIciRNS) és csak introni (ciRNS) circRNS-eket is. Az EIciRNS funkcióit ismertetjük részletesebben, amelyek hasonlítanak a ciRNS hatásmechanizmusához.

Az EIciRNS-ekről úgy találták, hogy koimmunprecipitálódnak a sejtmagi RNAPII-vel. Az EIciRNS Ul snRNS-hez kapcsolódását írták le, ami stimulálja mind a lineáris mRNS, mind a cirkuláris EIciRNS képződését, ezáltal létrehozva egy 'feed-forward loop'-ot (2. ábra). Feltehetőleg az EIciRNS az őt hordozó gén helyére po-

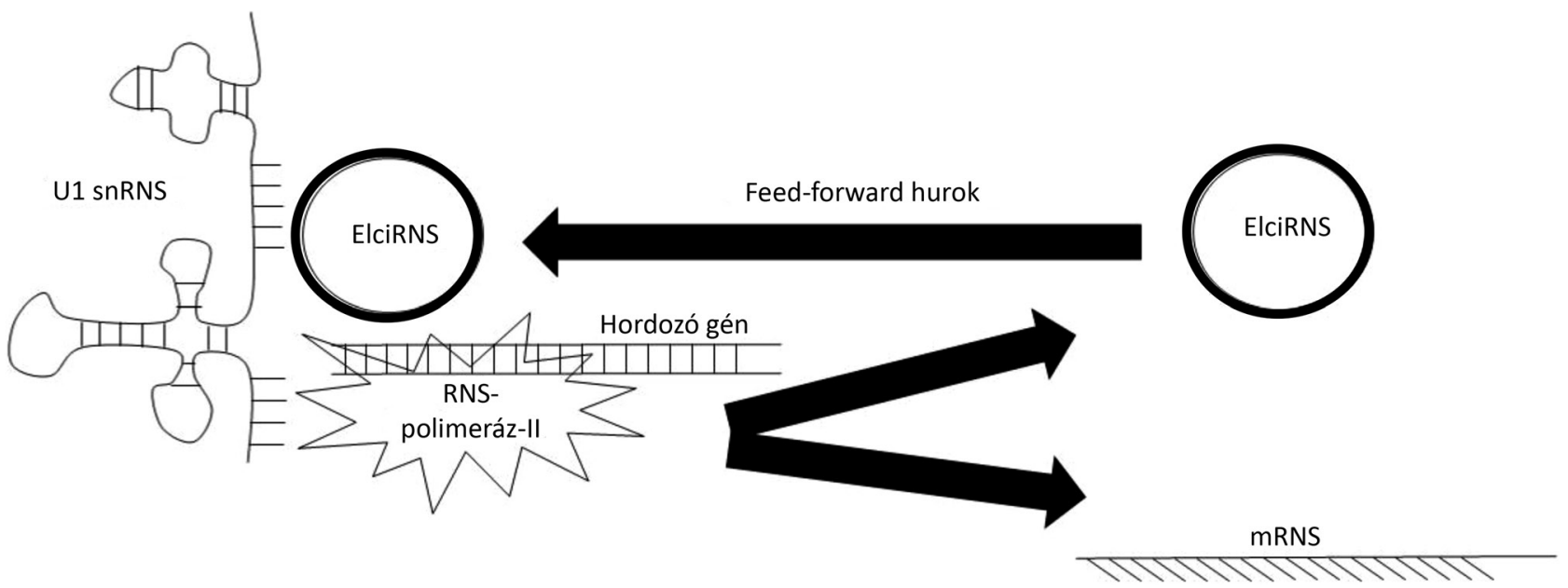

2. ábra $\quad$ Az EIciRNS-ek transzkripcióra kifejtett hatásai. Az EIciRNS-ek a saját kifejeződésüket növelve 'feed-forward' hurkot (hosszú nyíl) hoznak létre, illet ve növelik a hordozó gén mRNS-kifejeződését is; rövid nyíl: a transzkripció folyamata

EIciRNS = exon-intron szekvenciákat tartalmazó cirkuláris RNS; mRNS = hírvivő RNS; snRNS = kis magi RNS; RNS = ribonukleinsav 

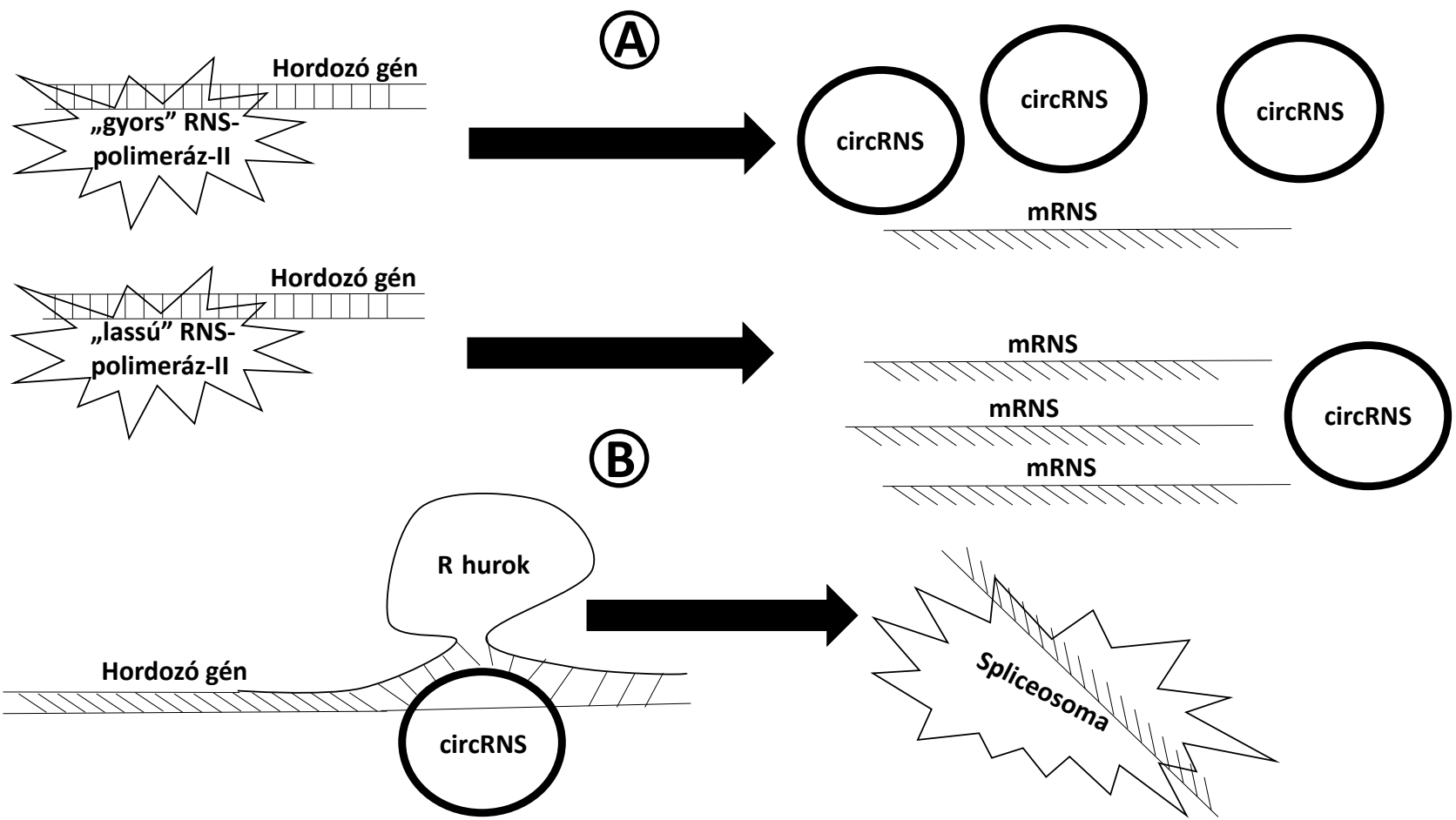

3. ábra

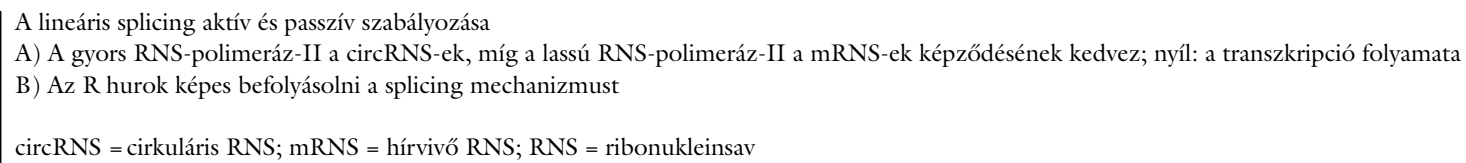

zicionálja az Ul snRNS-t, így az stimulálni tudja az RNAPII aktivitását, mint ahogyan az Ul-ról szóló korábbi tanulmányok is leírták már ezen funkcióját [32]. Az EIciRNS-ek magi tartózkodásából és saját lókuszán való pozitív hatásából ítélve az őt hordozó gének ciszregulátorainak tekinthetők.

3. Jóllehet az RNS-ek cirkularizálódása >100-szor ritkábban zajlik le a lineáris splicingnál, egyre inkább elterjedőben van az a nézet, miszerint két, egymással kompetícióban álló folyamatról beszélünk. A circRNS-eknek az e fejezet bevezetőjében említett funkciói közül jelenleg a splicing modulációját tartják a legelterjedtebb és legáltalánosabb funkciónak [33]. A splicing modulációját a kísérletek alapján „passzív” és „aktív” elméletekkel írhatjuk le. A passzív mechanizmus egyik feltételezett oka a mechanisztikus elmélet szerint az ún. „kinetikus kapcsolás” elve. Az elképzelés szerint az elongáció sebessége befolyásolja a kotranszkripciós splicingot, vagyis vannak exonok, amelyek gyenge splicing hellyel rendelkeznek, és ezen exonokat csak egy eléggé lassú RNAPII ismeri fel és építi be az mRNS-be. Másik oldalról megközelítve azt találták, hogy kismértékben (1,2-szer) gyorsabb elongáció jellemző a circRNS-eket tartalmazó gének esetében a circRNS-t nem tartalmazókhoz képest (3/A ábra) [33]. Az „aktív” modell a lineáris és backsplicing közötti kapcsolatot a hibrid circRNS:DNS eredendően tökéletlen illeszkedésére vezeti vissza. A DNS transzkripciója során az intronok kivágódnak, ezért a relatíve rövidebb circRNS DNS-hez való kapcsolódása $\mathrm{R}$ alakú hurkot hoz létre (3/B ábra). A circRNS-ek ezen R hurkairól kimutatták, hogy képesek szabályozni a lineáris alternatív splicingot [34].

4. Mind ez idáig két circRNS-rôl mutatták ki transzlációmodifikáló hatásukat. A $\operatorname{circANRIL~az~egyik,~amely~}$ az rRNS-processzáló komplex gátlása révén fejti ki hatását, a másik a $\operatorname{circPABPN1~központi~fehérjét~gátló~me-~}$ chanizmussal járul hozzá a transzláció gátlásához. Mára már ismert, hogy az ANRIL-lncRNS kifejeződésének megváltozása számos betegség rizikóját befolyásolja, ideértve a tumorokat és a cardiovascularis betegségeket [35]. A $\operatorname{circANRIL~a~funkcióját~tekintve~potenciális~fé-~}$ kezője lehet a sejtkárosodáshoz asszociált, lineáris RNS által kiváltott túlburjánzásnak, amit az atherogen állapottal hoztak összefüggésbe. Az ANRIL egy olyan különleges lókusz, ahol a circRNS antagonizálja a rokon RNS-transzkriptumot, méghozzá a lineáris transzkriptum által ellátott 'downstream' cellularis funkciók gátlásával (4. ábra). A circPABPN1 ezzel szemben specifikusan a társ $\mathrm{mRNS}$ befolyásolásán keresztül hat a transzláció folyamatára. HeLa-sejteken történt vizsgálatoknak köszönhetően a HuR-ról mint RNS-kötő fehérjéről (RBP)

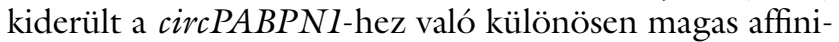
tása [36]. A HuR egy sor mRNS és nem kódoló RNS stabilitását képes növelni, valamint a splicing koordinációjában is részt vesz. Megállapították, hogy a $\operatorname{circPABPN1}$ túlexpresszált állapotban gátolja többek között a HuRnak a $P A B P N 1$-mRNS-sel való kölcsönhatását, ennek következtében kevesebb PABPN1-mRNS került transz- 


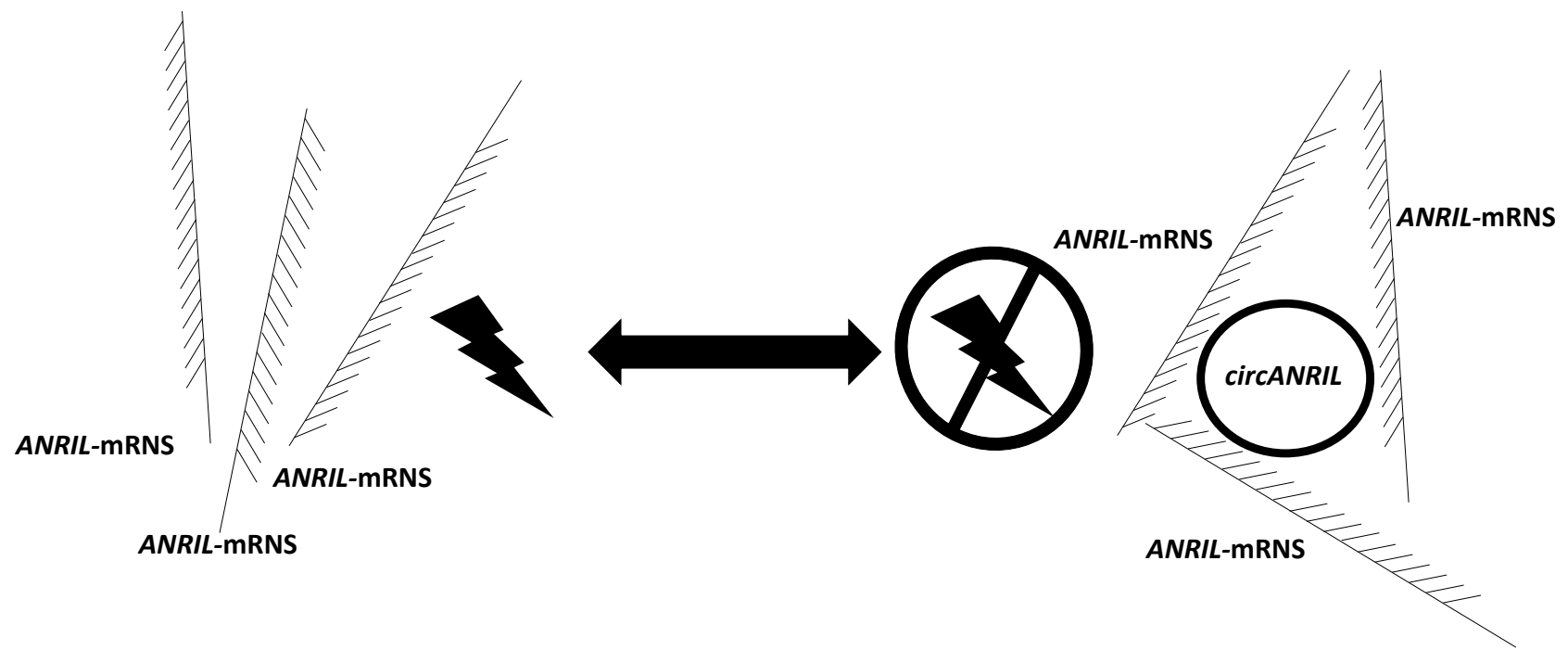

A lineáris ANRIL fokozza a cardiovascuralis rizikót (villámalakzat)

A circANRIL gátolja lineáris társát

4. ábra

A circANRIL cardioprotectiv szerepe. A circANRIL jelenlétében az ANRIL-mRNS nem képes fokozni a cardiovascularis rizikót; nyíl: az ANRILmRNS egyensúlyi állapotának eltolódása aktív (balra), illetve passzív (jobbra) irányba

ANRIL = antisense non-coding RNA in the INK4 locus; circANRIL = cirkuláris antisense non-coding RNA in the INK4 locus; mRNS = hírvivő RNS

lációra (5. ábra) [37]. A hipotézisek szintjén érdekes kitekintést nyújthat a további RBP-k, circRNS-ek és lineáris mRNS-ek közötti kapcsolat ilyen módon való átgondolására.

5. A circRNS-ekból kiinduló transzláció elméletben nagyban megnövelné a genom kódolóképességét, nem beszélve annak evolúciós vonatkozásairól. Eukaryotákban a transzláció standard módja az ún. Kozak-szekvencia / 5' „sapkától” függő ribosomabelépés, de amikor egy „belső ribosomabelépési hely” (IRES) jelen van, a $40 \mathrm{~S}$ ribosomalis alegység összekapcsolódhat az érett mRNS-sel, még akkor is, ha az nem tartalmaz szabad $5^{\prime}$ véget [38]. A legfejlettebb tömegspektrometriát alkalmazó, az endogén circRNS transzlációját célzó kutatások eddig két esetben szolgáltak bizonyítékkal: a $\operatorname{circMbl}$ és a circZNF609 esetében, habár funkciójuk pontos leírása ez idáig nem ismeretes $[39,40]$.
6. A CDK2 a sejtciklus G1-S-fázis-átalakulásában egy kulcsfontosságú szabályozó fehérje. A CDK2 a ciklin Ehez kötődve képes elindítani a Gl-S-átalakulást. Az elóbbi folyamatot a p21 fehérje gátolja a CDK2-vel való kapcsolódás révén. Mindezen felül kimutatták, hogy a circFoxo3 tumorszuppresszor circRNS szimultán képes kapcsolatba lépni a p21 és CDK2 szabályozómolekulákkal, ezáltal létrehozva egy olyan hármas katalitikus komplexet, amely még hatékonyabban gátolja a CDK2 sejtciklust előmozdító hatását [30].

\section{A circRNS-ek tumorbiológiai szerepe}

A circRNS-ek két okból is érdekesek a betegségek kontextusában. Egyrészt potenciálisan egy új, a vérben keringő biomarkerként szolgálhatnak, tudvalévő ugyanis a
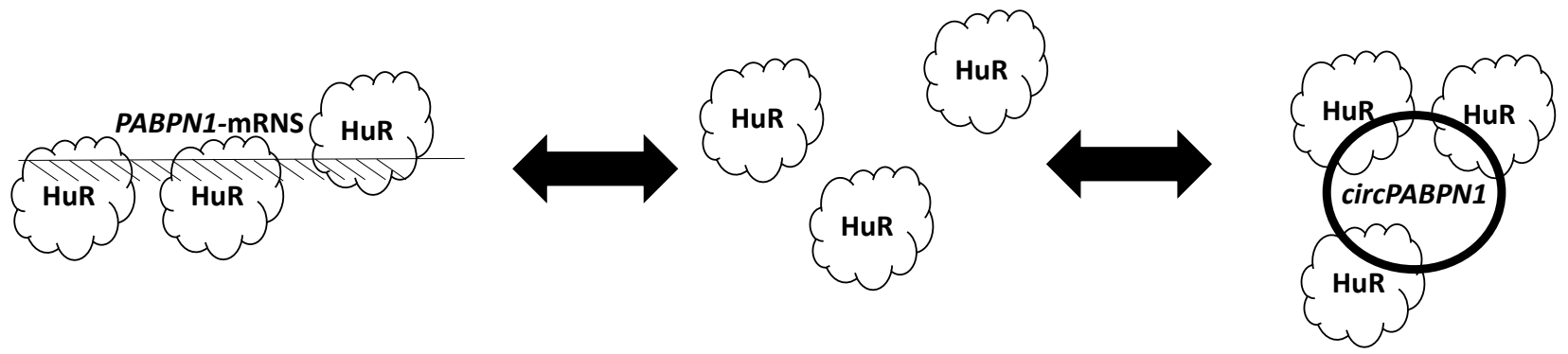

\section{A HuR mRNS-stabilizáló hatásáról ismert}

A circPABPN1 gátolja a HuR-t

5. ábra

A cirkuláris RNS-ek RBP-kötő funkciója. A circPABPNl jelenlétében a HuR RBP nem képes stabilizálni a PABPNl-mRNS-t; nyíl: a HuR RBP egyensúlyi állapotának eltolódása aktív (balra), illetve passzív (jobbra) irányba

circPABPNI = cirkuláris PABPNI; HuR = human antigen R; mRNS = hírvivő-RNS; PABPNl = polyadenylate-binding nuclear protein $1 ; \mathrm{RBP}=$ RNS-kötő fehérje; RNS = ribonukleinsav 
circRNS-ek nagyfokú stabilitása egyéb biomolekulákhoz, mint például a lineáris RNS-ekhez vagy peptidekhez viszonyítva - mindez pedig egy különösen releváns paraméternek tünik. Másrészt több tucat circRNS vesz részt a különböző tumorképző folyamatokban, például a circHIPK colorectalis, hepatocellularis, vese-, húgyhólyag-, prosztata-, mell- és gyomorrákban is miRNSszivacsként funkcionál, míg a bsa_circ_0004277 potenciális diagnosztikai marker és terápiás célpont lehet az acut myeloid leukaemiában [41, 42].

2013-ban az ENCODE adatait felhasználva nagy áteresztőképességű RNS-szekvenálás segítségével kimutatták a circRNS-ek bőséges és egyedi kifejeződését különböző tumoros sejtvonalakban [43]. Maga a tumorgenezis számos molekuláris változást magában foglal, többek között a genetikai mutációkat és a génexpressziós módosulásokat.

A circRNS-ek miRNS-ekkel fennálló kapcsolata kiemelendő. A circRNS-ek egyfajta „szivacsként” képesek megkötni a miRNS-transzkriptumokat, ezzel az epigenetikai módosítással egyfajta endogén RNS-kompetíciót hozva létre. A leginkább tanulmányozott ebből a szempontból is a ciRS-7, amely relatíve magas kifejeződési rátával és stabilitással bír, és képes szupprimálni a miR-7et, ezáltal növelve a miR-7 'target' gének expresszióját. Tekintettel arra, hogy a miR-7 közvetlenül onkogének (például EGFR, PIK3CD , IRS1 és 2, Rafl, Pakl, Ack1) expresszióját gátolja, az előbbi folyamat eredő hatásaként hozzájárul a tumorprogresszióhoz [44].

$\mathrm{Az}$ epithelialis-mesenchymalis átalakulás (EMT) fontos szerepet játszik a tumorok és metastasisok kialakulásában, a circRNS-ekkel felfedezett kapcsolatuk pedig nagyban hozzájárulhat a tumorprogresszió megértéséhez. A circRNS-ek biogenezisében részt vevő egyik leginkább vizsgált fehérje a QKI-nek nevezett mesenchymalis splicing faktor, amely képes akár de novo circRNS-ek létrehozására [25]. A QKI-ről kimutatták továbbá, hogy tumorszuppresszor tulajdonságú, és tüdőrákban a downregulációját két független csoport is szignifikánsan roszszabb prognózissal hozta összefüggésbe $[45,46]$.

A daganatokban gyakori genetikai eltérések - mint a pontmutációk, kromoszomális deletiók, amplifikációk és transzlokációk - döntő szerepet játszanak a tumorgenezisben [47]. Az utóbbival szoros összefüggésben egyre több adat áll rendelkezésünkre a fúziós circRNS-ekkel kapcsolatban, amelyek szintén a kromoszomális transzlokációk során képződnek, és potenciális diagnosztikai, terápiás szerepük lehet [48].

Mindezek mellett a közelmúltban fény derült a circRNS-ek transzlációs képességére, miszerint egyes circRNS-ek bizonyos szövetekben, bizonyos körülmények között transzlálódnak, habár a tumorgenezisben betöltött szerepük még felderítésre vár [39].

Az elméleti áttekintés után álljon itt néhány példa a circRNS-ek daganatokban betöltött szerepéről. A tumorgenezis számos molekuláris változást magában foglal, így a genetikai mutációkat és a génexpresszió változá- sát. A circRNS-ek tumorgenezisben betöltött szerepére egy igen széles körú és specifikus evidenciákat felsorakoztató közelmúltbeli tanulmány világított rá, amely több olyan circRNS-t azonosított, amely a tumorgenezis centrális folyamataihoz kötődik [48]. Bizonyos kromoszómatranszlokációk és -újrarendeződések ismerten előfordulnak több daganatban is, mint például leukaemiában (PML/RARa és MLL/AF9), Ewing-sarcomában (EWSRl/FLIl) és tüdőrákban (EML4/ALKl). Ennek következtében az mRNS hibás szabályozó hatások alá kerül, vagy maga a lineáris mRNS szekvenciája esik a fúzió áldozatává és válik egy csapásra onkogén természetüvé. A transzlokációk circRNS-eket is érinthetnek. Ezt a nemrégiben felfedezett aberráns transzkriptumot fúziós circRNS-nek (f-circRNS) nevezték el. A circRNS-ek kísérletes túlexpresszáltatása in vivo és további, csontvelőtranszplantációt követő szubletális irradiáción átesett, majd visszatranszplantált egerekkel való kísérletek felfedték a f-circRNS mediálta sejttranszformációt, tumorképző szerepét [48]. Ezen f-circRNS-ek megtalálhatók a citoszólikus és nukleáris kompartmentben is, de elsődleges molekuláris mechanizmusuk továbbra sem ismert. A molekuláris mechanizmusok megismerése után a releváns f-circRNS-ek gátlása újabb eszközt adhat a kutató, majd a klinikus kezébe a tumorellenes terápiában és akár a gyógyszer-rezisztencia leküzdésében.

A perifériás vérből kinyert szabad circRNS-ek szekvenálása jelenleg a tumorbiomarker-kutatás egyik megközelítése. Egy másik kiemelendő módszer a daganatos szövetek profilozása és kontroll egészséges szövetekkel való összevetése, a circRNS-kifejeződés különbsége után kutatva. Ez utóbbi kutatások már több mint 20 circRNS-t írtak le különböző daganatokban. Ezen kutatások alapján a circRNS-ek elsődleges effektor mechanizmusaként a miRNS „szivacs” funkcióját feltételezik. Egy tanulmány a circHIPK3-at emelte ki a colorectalis, gyomor-, húgyhólyag, mell-, hepatocellularis, prosztata- és világossejtes vesedaganatok RNS-expressziójának profilozása alapján. A circHIPK3 kifejeződése lineáris mRNS megfelelőjéhez képest magas arányban reprezentálódott, és 2-4-szeres túlexpresszálódást mutatott legalább egy rákos sejtvonalon [42]. A circHIPK3 9 különböző miRNS-t képes megkötni relatíve alacsony számú miRNSkötő hellyel (1-2), ami klasszikusan nem tekinthető miRNS-szivacsnak. Mégis, a circHIPK3-hoz kötődő miRNS-eknek feltételezetten növekedésgátló hatásuk van, amelyet előzetesen több független tanulmány is kimutatott (miR-124) [42]. Amikor siRNS-ekkel vették célba a circHIPK3-at, csökkent sejtproliferációt (1,5-2-szeresen) találtak a daganatos sejtvonalakban. A bemutatott bizonyítékok összhangban állnak azzal a lehetőséggel, miszerint a HIPK3-circRNS növekedést gátló funkciókat betöltő miRNS-eket szekvesztrál, eredő hatásként sejtproliferációt eredményezve. Egy másik megközelítésben, a közelmúltban feltérképezésre került néhány betegség- és hajlamasszociált genomi szintű asszociációs (GWAS) vizsgálatokból nyert SNP (single-nucleotide 
polymorphism, egy nukleotidot érintő polimorfizmus), amelyeket összevetettek az összes ismert circRNS-képző lókusszal, és számos, feltételezetten betegségasszociált circRNS bukkant fel, csakhogy újra rámutasson: a circRNS-ek biológiája új sugárút lehet számos betegség megértéséhez a jövőben.

\section{A circRNS mint biomarker}

Egyes közelmúltbeli tanulmányok a vérben igyekezték felderíteni, vajon az tartalmaz-e keringő circRNS-eket. A remények szerint a betegségspecifikus circRNS-expressziós profilozás segítségével a folyadékbiopszia új szintre emelheti a klinikai diagnosztika tárházát.

A circRNS-ekről kimutatták, hogy sejt/szövet specifikusan fejeződnek ki, méghozzá a sejt teljes lineáris-RNSkifejeződésétől eltérő mintázatban, ami alapul szolgálhat a circRNS-ek klinikai alkalmazhatóságának [43].

Az extracellularis RNS (exRNS) mint a testnedvekből kinyerhető újfajta biomarker egyre gyakrabban áll a kutatások középpontjában. A lineáris RNS-ekhez viszonyítva a circRNS-ek igen nagy stabilitást, hosszabb felezési időt mutatnak, a szabad végek hiányának és az exonukleáz degradáló hatásával szembeni rezisztenciának köszönhetően [23]. A circRNS megtalálható az exosomákban, a sejtmentes nyálban, a vizeletben és a plazmában is. Az előbbi tulajdonságból adódóan a circRNS-ek a folyadékbiopsziás diagnosztika és a személyre szabott medicina jövőbeli biomarkerei lehetnek.

Valójában a circRNS-ek a vér transzkriptomjának normál részét képezik, mi több, nagyobb számban találhatók meg a perifériás vérben, mint magában a szolid szövetben. Például egy sor, bőségesen előforduló circRNS-ről négyszeresen magasabb szintet állapítottak meg a társ lineáris RNS-ekhez képest, illetve 2-5-ször nagyobb mennyiségben fordultak elő magában a vérben, mint a vizsgált máj- és agyszövetben. E megfigyelés magyarázata még várat magára. Összehasonlításképp, miközben az endogén sejten belüli circRNS életideje 1-2 napra tehető, addig a csupasz, szérumba juttatott circRNS féléletideje 15 másodperc körüli [30]. Ez esetben úgy gondolják, hogy a védtelen circRNS-ek is áldozatul eshetnek az RNáz típusú endonukleázok hatásainak. Mindez nem meglepő a terápiában is használatos szabadon keringő DNS (cfDNS) relatíve rövid féléletidejét tekintve. A szabad DNS kimutathatóságának hátterében folyamatos szöveti kibocsátást vagy burkolt állapotát feltételezik [22]. Ezen vélelmezett burokmechanizmus létezésére több álláspont is napvilágot látott: a vérben keringő DNS/RNS-t összefüggésbe hozták különböző keringó extracellularis foszfolipid membránhoz kötött vesiculákkal, mind a 40-100 nm-es exosomákkal, mind a 100-1000 nm-es tartományba eső microvesiculákkal. Feltehetően a keringő DNS/RNS-ek stabilizációjáhaz szintén hozzájárulnak az apoptotikus testekből származó vesiculák, endoplazmatikus reticulum fragmentek vagy a fehérjékhez való kötődés [22]. Példaként álljon itt a már említett miRNS-ek AGO2-höz vagy HDL-hez való kötődése, amely lehetôvé teheti ezek hormonszerú hatásait is [16]. A jövő kutatásainak egyik feladata kideríteni a szabadon keringő circRNS-eket a lebomlástól védő mechanizmusoknak a részleteit.

Mostanáig néhány tucat circRNS került profilozásra a perifériás vérből, amelyek alkalmasak lehetnek a coronariabetegségek, a szolid és nem szolid tumorok, a diabetes, a sclerosis multiplex stb. állapotának követésére [22]. A circRNS-ek standardizációja, azonosítása és kvantifikációja még nem elég kiforrott, megközelítésükben eltérőek, így az összhangban álló eredmények eléréséhez további vizsgálatokra van szükség.

\section{A jövő lehetőségei}

A Nature-ben megjelent 2018. évi, „Circular RNAs in cancer: opportunities and challenges in the field" címú cikk ajánlása szerint a circRNS-t célzó kutatások még mindig gyerekcipőben járnak, amit az egyelőre hiányos nevezéktannal és a nem egységes „reporting” standarddal magyaráz [23]. Javasolja tehát, hogy a jövőbeli tanulmányok biztosítsanak 'circBase ID'-t a tanulmányozott circRNS-ek számára, illetve nevezzék el őket a hordozó gén elé írt „circ” előtag segítségével. Amennyiben nem található meg a circBase adatbázisában, a genomban elfoglalt helyzetéről adjanak tájékoztatást. A circRNS-ek legtöbb, teljes genomra kiterjedő vizsgálatához microarray-t vagy újgenerációs szekvenálást használtak a daganatosan elfajult szövetból és a környező nem daganatos szövetből, ám a részletes, patológus által elvégzett minták vizsgálata az esetek túlnyomó részében elmaradt. Minthogy a legtöbb kutatás retrospektív módon határozta meg a kandidáns circRNS biomarkereket, érdekes volna látni, hogyan teljesítenek a prospektív klinikai vizsgálatokban. Továbbá az új, tumorasszociált circRNS-ek felfedezése megköveteli az objektív, részrehajlástól mentes megközelítést, mint amilyen például az RNA-seq. Arany standard hiányában azonban tanácsos egynél több circRNS-predikciós algoritmust elvégezni az RNA-seq adatain az elsőfajú hibák kiküszöbölése érdekében. Még említést érdemel, hogy az RT-qPCR hatékony módszer ugyan az eredmények validálására, a reverz transzkripció során hibák léphetnek föl, amelyek fals pozitivitáshoz vezethetnek, csakúgy, mint a lineáris mRNS-exon ismétlődéseinek esetén, ami RNáz R-előkezeléssel vagy polyAdúsítással különböztethető meg a circRNS-től. A klasszikus 'Northern blotting'-ot tekinthetjük az új circRNS-ek validációjára a leginkább alkalmas módszernek [23].

Az in situ hibridizáció egy másik előnyös megközelítés a circRNS expressziójának vizsgálatára. Egyrészt térbeli információt nyújt a specifikus circRNS-ekról, másrészt kompatibilis a formalinfixált paraffinba ágyazott mintákkal. Az új technológiák alkalmazhatósága még felderítésre vár, ilyen például a nanopore RNA sequencing (Oxford Nanopore Technologies, Oxford, Egyesült 
Királyság) és a NanoString Technologies (Seattle, WA, Amerikai Egyesült Államok).

Noha a circRNS-kutatás még csak a hajnalát éli, és a tumorgenezisben betöltött pontos funkciója még értelmezésre vár, a circRNS nemcsak ígéretes biomarker, de potenciális tumorellenes gyógyszerek célpontja is lehet.

Anyagi támogatás: A közlemény megírása anyagi támogatásban nem részesült.

Szerzői munkamegosztás: Az összefoglaló cikk a két szerző közös munkája. A cikk végleges változatát mindkét szerző elolvasta és jóváhagyta.

Érdekeltségek: A szerzőknek nincsenek érdekeltségeik.

\section{Irodalom}

[1] Kaikkonen MU, Lam MT, Glass CK. Non-coding RNAs as regulators of gene expression and epigenetics. Cardiovasc Res. 2011; 90: 430-440.

[2] Ponting CP, Oliver PL, Reik W. Evolution and functions of long noncoding RNAs. Cell 2009; 136: 629-641.

[3] De Santa F, Barozzi I, Mietton F, et al. A large fraction of extragenic RNA pol II transcription sites overlap enhancers. PLOS Biol. 2010; 8: el000384.

[4] Ørom UA, Derrien T, Beringer M, et al. Long noncoding RNAs with enhancer-like function in human cells. Cell 2010; 143: 4658.

[5] Krol J, Loedige I, Filipowicz W. The widespread regulation of microRNA biogenesis, function and decay. Nat Rev Genet. 2010; 11: 597-610.

[6] Guo Z, Maki M, Ding R, et al. Genome-wide survey of tissuespecific microRNA and transcription factor regulatory networks in 12 tissues. Sci Rep. 2014; 4: 5150 .

[7] Politz JC, Hogan EM, Pederson T. MicroRNAs with a nucleolar location. RNA 2009; 15: 1705-1715.

[8] Bianchi M, Renzini A, Adamo S, et al. Coordinated actions of microRNAs with other epigenetic factors regulate skeletal muscle development and adaptation. Int J Mol Sci. 2017; 18: 840.

[9] Bartel DP. MicroRNAs: genomics, biogenesis, mechanism, and function. Cell 2004; 116: 281-297.

[10] Kozomara A, Griffiths-Jones S. miRBase: annotating high confidence microRNAs using deep sequencing data. Nucleic Acids Res. 2014; 42: D68-D73.

[11] Ma Y, She XG, Ming YZ, et al. miR-24 promotes the proliferation and invasion of HCC cells by targeting SOX7. Tumour Biol. 2014; 35: 10731-10736.

[12] Gao Y, Liu Y, Du L, et al. Down-regulation of miR-24-3p in colorectal cancer is associated with malignant behavior. Med Oncol. $2015 ; 32: 362$.

[13] Weber JA, Baxter DH, Zhang $S$, et al. The microRNA spectrum in 12 body fluids. Clin Chem. 2010; 56: 1733-1741.

[14] Hall JS, Taylor J, Valentine HR, et al. Enhanced stability of microRNA expression facilitates classification of FFPE tumour samples exhibiting near total mRNA degradation. Br J Cancer 2012; 107: 684-694.

[15] Kosaka N, Iguchi H, Joshioka Y, et al. Secretory mechanisms and intercellular transfer of microRNAs in living cells. J Biol Chem. 2010; 285: 17442-17452.

[16] Arroyo JD, Chevillet JR, Kroh EM, et al. Argonaute2 complexes carry a population of circulating microRNAs independent of vesicles in human plasma. Proc Natl Acad Sci. 2011; 108: 50035008 .
[17] Vickers KC, Palmisano BT, Shoucri BM, et al. MicroRNAs are transported in plasma and delivered to recipient cells by highdensity lipoproteins. Nat Cell Biol. 2011; 13: 423-433. [Correction: Nat Cell Biol. 2015; 17: 104.]

[18] Decmann Á, Perge P, Nagy Z, et al. Circulating microRNAs in the diagnostics of endocrine neoplasms. [Keringő mikroRNS-ek az endokrin daganatok diagnosztikájában.] Orv Hetil. 2017; 158: 483-490. [Hungarian]

[19] Ebbesen KK, Hansen TB, Kjems J. Insights into circular RNA biology. RNA Biol. 2017; 14: 1035-1045.

[20] Ashwal-Fluss R, Meyer M, Pamudurti NR, et al. circRNA biogenesis competes with pre-mRNA splicing. Mol Cell 2014; 56: $55-66$.

[21] Giannoukos G, Ciulla DM, Huang K, et al. Efficient and robust RNA-seq process for cultured bacteria and complex community transcriptomes. Genome Biol. 2012; 13: R23.

[22] Holdt LM, Kohlmaier A, Teupser D. Molecular roles and function of circular RNAs in eukaryotic cells. Cell Mol Life Sci. 2018; 75: 1071-1098.

[23] Kristensen LS, Hansen TB, Venø MT, et al. Circular RNAs in cancer: opportunities and challenges in the field. Oncogene 2018; 37: 555-565.

[24] Li X, Yang L, Chen LL. The biogenesis, functions, and challenges of circular RNAs. Mol Cell 2018; 71: 428-442.

[25] Conn SJ, Pillman KA, Toubia J, et al. The RNA binding protein quaking regulates formation of circRNAs. Cell 2015; 160: $1125-1134$.

[26] Jeck WR, Sorrentino JA, Wang K, et al. Circular RNAs are abundant, conserved, and associated with ALU repeats. RNA 2013; 19: 141-157. [Correction: RNA 2013; 19: 426.]

[27] Enuka Y, Lauriola M, Feldman ME, et al. Circular RNAs are long-lived and display only minimal early alterations in response to a growth factor. Nucleic Acids Res. 2016; 44: 1370-1383.

[28] Alhasan AA, Izuogu OG, Al-Balool HH, et al. Circular RNA enrichment in platelets is a signature of transcriptome degradation. Blood 2016; 127: el-ell.

[29] Rybak-Wolf A, Stottmester C, Glažar P, et al. Circular RNAs in the mammalian brain are highly abundant, conserved, and dynamically expressed. Mol Cell 2015; 58: 870-885.

[30] Du WW, Yang W, Liu E, et al. Foxo3 circular RNA retards cell cycle progression via forming ternary complexes with p21 and CDK2. Nucleic Acids Res. 2016; 44: 2846-2858.

[31] Hansen TB, Jensen TI, Clausen BH, et al. Natural RNA circles function as efficient microRNA sponges. Nature 2013; 495: 384-388.

[32] Li Z, Huang C, Bao C, et al. Exon-intron circular RNAs regulate transcription in the nucleus. Nat Struct Mol Biol. 2015; 22: 256-264. [Correction: Nat Struct Mol Biol. 2017; 24: 194.]

[33] Zhang Y, Zhang XO, Chen T, et al. Circular intronic long noncoding RNAs. Mol Cell 2013; 51: 792-806.

[34] Conn VM, Hugouvieux V, Nayak A, et al. A circRNA from SEPALLATA3 regulates splicing of its cognate mRNA through R-loop formation. Nat Plants 2017; 3: 17053.

[35] Holdt LM, Hoffmann S, Sass K, et al. Alu elements in ANRIL non-coding RNA at chromosome 9p21 modulate atherogenic cell functions through trans-regulation of gene networks. PLOS Genet. 2013; 9: el003588.

[36] Abdelmohsen K, Panda AC, Munk R, et al. Identification of HuR target circular RNAs uncovers suppression of PABPNl translation by CircPABPN1. RNA Biol. 2017; 14: 361-369.

[37] Lebedeva S, Jens $M$, Theil $\mathrm{K}$, et al. Transcriptome-wide analysis of regulatory interactions of the RNA-binding protein HuR. Mol Cell 2011; 43: 340-352.

[38] Chen CY, Sarnow P. Initiation of protein synthesis by the eukaryotic translational apparatus on circular RNAs. Science 1995; 268 : 415-417. 
[39] Legnini I, Di Timoteo G, Rossi F, et al. Circ-ZNF609 is a circular RNA that can be translated and functions in myogenesis. Mol Cell 2017; 66: 22-37.e9.

[40] Pamudurti NR, Bartok O, Jens M, et al. Translation of circRNAs. Mol Cell 2017; 66: 9-21.e7.

[41] Li W, Zhong C, Jiao J, et al. Characterization of hsa_circ_0004277 as a new biomarker for acute myeloid leukemia via circular RNA profile and bioinformatics analysis. Int J Mol Sci. 2017; 18: 597.

[42] Zheng Q, Bao C, Guo W, et al. Circular RNA profiling reveals an abundant circHIPK 3 that regulates cell growth by sponging multiple miRNAs. Nat Commun. 2016; 7: 11215.

[43] Salzman J, Chen RE, Osen MN, et al. Cell-type specific features of circular RNA expression. PLOS Genet. 2013; 9(9): el 003777. [Correction: PLOS Genet 2013; 9(12): 10.1371.]

[44] Hansen TB, Kjems J, Damgaard CK. Circular RNA and miR-7 in cancer. Cancer Res. 2013; 73: 5609-5612.
[45] Zong FY, Fu X, Wei WJ, et al. The RNA-binding protein QKI suppresses cancer-associated aberrant splicing. PLOS Genet. 2014; 10: el004289.

[46] de Miguel FJ, Pajares MJ, Martínez-Terroba E, et al. A largescale analysis of alternative splicing reveals a key role of QKI in lung cancer. Mol Oncol. 2016; 10: 1437-1449.

[47] Chin L, Andersen JN, Futreal PA. Cancer genomics: from discovery science to personalized medicine. Nat Med. 2011; 17: 297-303.

[48] Guarnerio J, Bezzi M, Jeong JC, et al. Oncogenic role of fusioncircRNAs derived from cancer associated chromosomal translocations. Cell 2016; 165: 289-302.

(Igaz Péter dr.,

Budapest, Üllői út 26., 1085 e-mail: igaz.peter@med.semmelweis-univ.hu)

\section{Pályázati felhívás}

Dr. Fehér János professzornak, a Semmelweis Egyetem II. sz. Belgyógyászati Klinikája volt igazgatójának, az Orvosi Hetilap volt föszerkesztöjének emlékére 2011-ben alapítvány létesült.

A Dr. Fehér János Emlékére Alapítvány fö célja a belgyógyászat, különösen a hepatológia szabad gyökös és immunológiai vonatkozású témaköreinek kutatása, fejlesztése, támogatása, illetve ösztönzése oly módon, hogy az alapítvány kamatából fiatal egyetemi oktatók, PhD-hallgatók és orvostanhallgatók részesüljenek.

\section{A pályázatok benyújtásának határideje: 2020. április 15.}

A dolgozatot „Dr. Fehér János pályázat” megjelöléssel kell benyújtani, és a pályázathoz mellékelni kell a pályázó önéletrajzát is.

A dolgozatot a Dr. Fehér János Emlékére Alapítvány Kuratóriuma elnökének

(Dr. Hagymási Krisztina) vagy titkárának (Dr. Lengyel Gabriella) kell eljuttatni.

Beküldési cím: Semmelweis Egyetem, II. Belgyógyászati Klinika 1088 Budapest, Szentkirályi u. 46.

A díj odaítéléséről a kuratórium dönt. A díj átadására az Orvosi Hetilap Markusovszky-ünnepségén kerül sor, ahol a nyertes pályázó 5 perces előadásban foglalhatja össze az eredményeit.

A cikk a Creative Commons Attribution 4.0 International License (https://creativecommons.org/licenses/by/4.0/) feltételei szerint publikált Open Access közlemény, melynek szellemében a cikk bármilyen médiumban szabadon felhasználható, megosztható és újraközölhető, feltéve, hogy az eredeti szerző és a közlés helye, illetve a CC License linkje és az esetlegesen végrehajtott módosítások feltüntetésre kerülnek. (SID_1) 